\title{
RENAL CLEARANCE AND URINARY EXCRETION OF MOXIFLOXACIN IN HEALTHY MALE VOLUNTEERS
}

\author{
Asia Farid*, Tanweer Khaliq, Hafiz Alam Sher, Atifa Mushtaq, Abdullah Abid \\ Institute of Pharmacy, Physiology and Pharmacology, University of Agriculture Faisalabad, Faisalabad, Pakistan \\ *Corresponding Author Email: asiafaridsa@gmail.com
}

This is an open access article distributed under the Creative Commons Attribution License, which permits unrestricted use, distribution, and reproduction in any medium, provided the original work is properly cited.

\section{ARTICLE DETAILS}

Article History:

Received 12 November 2017 Accepted 12 December 2017 Available online 1 January 2018

\section{ABSTRACT}

Moxifloxacin is a $4^{\text {th }}$ generation fluoroquinolone. Study was planned on renal clearance and urinary excretion of moxifloxacin on healthy male volunteers by applying sensitive, rapid and accurate HPLC-UC analytical method. For this study 8 healthy male subjects similar in all physical conditions were selected. Moxifloxacin (Avelox ${ }^{\circledR} 400$ mg) was administered orally under fasting conditions. First sample of urine and blood was collected before administration of moxifloxacin and other samples of blood were taken at $0.5,1.5,2.5,3.5 \mathrm{hr}$ and urine samples were withdrawn at 1,2 , $3,4,6,8,10,12,24,36$ and $48 \mathrm{hr}$. The $\mathrm{pH}$ of the samples was measured by $\mathrm{pH}$ meter. Blood and urine samples were analyzed with HPLC for drug determination. Endogenous creatinine was measured by reagent kit method. The plasma concentration of endogenous creatinine and drug were $12.61 \pm 0.85 \mu \mathrm{g} / \mathrm{mL}$ and $1.678 \pm 0.062 \mu \mathrm{g} / \mathrm{mL}$. The renal clearance of endogenous creatinine ranges from 1.17 to $3.18 \mathrm{ml} / \mathrm{min} / \mathrm{kg}$ with an average $\pm \mathrm{SE}$ value of $2.67 \pm 0.24$ $\mathrm{mL} / \mathrm{min} / \mathrm{Kg}$. Renal clearance of moxifloxacin was $0.476 \pm 0.04 \mathrm{~mL} / \mathrm{min} / \mathrm{Kg}$ ranged between $0.27-0.609 \mathrm{~mL} / \mathrm{min} / \mathrm{Kg}$ Urinary excretion of moxifloxacin calculated as cumulative percent dose excreted $20.48 \pm 0.88$. A positive relationship was found between diuresis and renal clearance of drug indicated that besides glomerular filtration passive diffusion is also involved at kidney tubular level.

\section{KEYWORDS}

Moxifloxacin, fluoroquinolone, Blood, Endogenous creatinine, glomerular filtration, kidney tubular.

\section{INTRODUCTION}

The fluoroquinolones are a rapidly growing family of synthetic antibiotics that has proved to be helpful in cure of number of ailments. Moxifloxacin is an important fluoroquinolone with broad spectrum of antibacterial activity being used to treat variety of infection in human being and animals. Moxifloxacin is readily absorbed and thoroughly distributed in body after oral dose. Moxifloxacin is not bio transformed by cytochrome P450 system rather it is metabolized by microsomal enzymes [1]. In clinical studies moxifloxacin has shown 88 - 97\% success rate and 90 $97 \%$ eradication rates of bacteria. No dose adjustment has been required in patients with renal impairment or mild to moderate hepatic dysfunction. Moxifloxacin is safe and effective antibiotic and very helpful in treatment of community acquired pneumonia and acute bacterial exacerbation of chronic bronchitis [2]

Asian population is living under a varying degree of geographical and environmental settings that could affect their lives in different ways. The knowledge related to health, disease, nutritional conditions, environmental and genetic factors effecting health states of man, is acquired from literature of the western countries, which are different from those of the Asian countries. Previous studies have indicated that drug disposition kinetics, renal clearance and urinary excretion should be determined in the environment and species where the drug is to be employed clinically $[3,4]$. The study of urinary excretion of a dug after administration of drug provides important information regarding distribution, absorption and excretion parameter of drug from body. Measurement of renal clearances is important in clinical practice. Determination of renal clearance is important to assess kidney function, response to treatment, progression of kidney disease and to assess the dialysis requirement [5].

There are many methods for the evaluation of moxifloxacin in human body fluids. These methods are reverse-phase HPLC/fluorescence, highperformance liquid chromatography (HPLC), capillary electrophoresis voltammetry. HPLC has been used commonly for the quantitative analysis of quinolones in animal tissues and body fluids [6]. The present study was conducted to increase the understanding of the contribution of factors such as demographics variability in the renal clearance and urinary excretion of this drug in indigenous conditions.

\section{MATERIALS AND METHODOLOGY}

\subsection{Chemicals}

A commercial preparation of Moxifloxacin, tablets Avelox ${ }^{\circledR}, 400 \mathrm{mg}$ (Bayer HealthCare, Pakistan) was used in the present study. Heparin sodium salt (B. Braun Melsungen AG, Germany), Moxifloxacin standard was $97.99 \%$ pure, Ethylene Diamine Tetraacetic Acid (EDTA), Acetonitrile (RCI LABSCAN LIMITED, THAILAND), Methanol (FISHER SCIENTIFIC LIMITED, UK), Deionized water, Dichloromethane Sodium chloride, Phosphate buffer. All the solvents were of analytical grade.

\subsection{Instrumentation and chromatography}

Chromatography was performed with a High-Performance Liquid Chromatograph (Sykam, S-1122) and analyses were determined using UV detector (Sykam, S-3210). A stainless-steel column packed with YMC pack A-312 (BDS-C18 with $250 \times 4.6 \mathrm{~mm}$ dimensions and $5 \mu \mathrm{m}$ particle size) was used. The output of the detector was monitored with computer software (Peak Simple Chromatography Data System, Buck Scientific Inc., East Norwalk). Analytical Balance (Sartorius, Germany). Centrifugation Machine (MSE Micro Centaur, Sanyo UK). Sonication apparatus (Oqawa seiki Co, Japan). Sample Injector Sykam S5111 Valve Bracket.

\subsection{Stock solutions and standards}

Moxifloxacin was made up as $1 \mathrm{mg} / \mathrm{ml}$ stock solutions in methanol and distilled water (1:10 by volume). The calibration curve of moxifloxacin in plasma was prepared by making the standard dilutions $(10-100 \mu \mathrm{g} / \mathrm{ml})$ from the moxifloxacin stock solution $(1 \mathrm{mg} / \mathrm{ml}$ ) prepared in drug-free (controlled) plasma. The calibration curves of moxifloxacin in controlled urine was prepared by making the standard dilutions $(320,160,80,40$ and $20 \mu \mathrm{g} / \mathrm{mL})$ 
from the stock solutions $(1 \mathrm{mg} / \mathrm{ml})$ of moxifloxacin prepared in drug-free controlled. Aliquots of these working standard solutions were stored at $20^{\circ} \mathrm{C}$. This range was based on the concentration of moxifloxacin in human plasma after oral administration of $400 \mathrm{mg}$ dose. These solutions were filtered through Whatman membrane filters of $0.45 \mathrm{~mm}$ pore size $(25 \mathrm{~mm}$ filter) and $20 \mu \mathrm{L}$ was injected into HPLC for analysis. Calibration graph was prepared by using peak area verses concentrations of working solutions.

\section{$2.4 \quad$ Study design}

Eight healthy male volunteers were recruited to participate in this study. The average age was 25years (range 25-27) and the average weight was70 $\mathrm{kg}$ range $(68-74 \mathrm{~kg})$. The study protocol was approved by the ethical committee at University of Agriculture Faisalabad. The nature of the study was explained to the volunteers and a written consent was obtained from each volunteer. All the volunteers had normal kidney and liver functions and were free from any chronic disease such as hypertension, diabetes, hypotension or liver abnormalities. First sample of urine and blood was collected before administration of moxifloxacin and other samples of blood were taken at $0.5,1.5,2.5,3.5 \mathrm{hr}$ and urine samples were withdrawn at $1,2,3,4,6,8,10,12,24,36$ and $48 \mathrm{hr}$.

\subsection{Plasma Sample Preparation}

Plasma was prepared from heparinized whole blood samples collected from the volunteers $250 \mu \mathrm{L}$ of the plasma samples were taken and transferred to $2 \mathrm{ml}$ polyethylene vial in which $1 \mathrm{ml}$ of acetonitrile and acetic acid were already added. The samples were centrifuged at $4000 \mathrm{rpm}$ for $1 \mathrm{~min}$. The aqueous layer was discarded, and the organic phase was transferred to $2 \mathrm{ml}$ glass vials. The solvent was evaporated to dryness at $40^{\circ} \mathrm{C}$ under stream of nitrogen. The residue was re-dissolved in $250 \mu \mathrm{L}$ of mobile phase, of which $20 \mu \mathrm{L}$ was taken and injected in chromatographic column for moxifloxacin analysis.

\subsection{Urine Sample Preparation}

Frozen urine was allowed to thaw at room temperature. Dichloromethane $(5 \mathrm{ml})$, sodium chloride $(0.25 \mathrm{~g}$ ) and $0.5 \mathrm{M}$ phosphate buffer ( $\mathrm{pH} 8.0$ ) (500 $\mu$ ) were added to $1.0 \mathrm{ml}$ of urine in a screw capped tube. After shaking with a vortex mixer for $10 \mathrm{~min}$ and centrifugation at $4000 \mathrm{rpm}$ for $15 \mathrm{~min}$, the aqueous layer was discarded. The remaining organic phase was transferred into a new glass tube and evaporated with a vacuum evaporator at $40^{\circ} \mathrm{C}$. The residue was reconstituted with $200 \mu \mathrm{L}$ of the mobile phase and $20 \mu 1$ were injected into the HPLC apparatus.

\subsection{Preparation of mobile phase}

The mobile phase was consisted of Acetonitrile, double distilled water and Methanol. The water for mobile phase was prepared by double glass distillation. The ratio of methanol, acetonitrile and water was 45:30:25. After mixing the solvents, mobile phase was passed through filtration assembly, having the filter paper size of $0.45 \mu \mathrm{m}$ Whatman (Schleicher \& Schuell $12.5 \mathrm{~mm}$. Then, the filtered mobile phase was sonicated for 15 minutes to remove any air bubbles.

\subsection{Creatinine analysis}

The creatinine concentration in plasma and urine samples was determined by using spectrophotometer (spectronic212, Bausch \& Lomb, Germany) according to method of Bonsnes and Taussky (1945) by Jaffereaction after treating creatinine reagent kit.

\section{RESULTS}

The renal clearance of creatinine and moxifloxacin and urinary excretion of moxifloxacin was investigated in eight healthy males after the per-oral dose (OD) of $400 \mathrm{mg}$ tablets. Blood and urine samples were collected at predetermined intervals of time for the measurement of diuresis (rate of urine flow), renal clearance of creatinine and moxifloxacin. Following result show Mean \pm S.E values of the above-mentioned variables.

\subsection{Renal clearance}

The results of renal clearance are summarized in the table1. The Mean \pm SE value of diuresis in male was $0.046 \pm 0.0015 \mathrm{~mL} / \mathrm{min} / \mathrm{kg}$. Value ranged from 0.043 to $0.05 \mathrm{~mL} / \mathrm{min} . / \mathrm{kg}$. The concentration of endogenous creatinine in plasma ranged from $10.2-17.2 \mu \mathrm{g} / \mathrm{mL}$ with a Mean $\pm \mathrm{SE}$ value $12.61 \pm 0.85 \mu \mathrm{g} / \mathrm{mL}$. The values of creatinine concentration in urine varied form $777.35 \mu \mathrm{g} / \mathrm{mL}$ to $1637.5 \mu \mathrm{g} / \mathrm{mL}$ with a Mean $\pm \mathrm{SE}$ value of $1130 \pm 96.09 \mu \mathrm{g} / \mathrm{mL}$. The Mean \pm SE value of renal clearance of endogenous creatinine found to be $2.67 \pm 0.24 \mathrm{~mL} / \mathrm{min} / \mathrm{kg}$. The Mean \pm SE value of plasma moxifloxacin concentration in the blood sample was found to be $1.68 \pm 0.05 \mu \mathrm{g} / \mathrm{mL}$ ranged from $1.55-1.89 \mu \mathrm{g} / \mathrm{ml}$. Mean $\pm \mathrm{SE}$ moxifloxacin concentration in urine sample was found to be $27.18 \pm 2.45$ $\mu \mathrm{g} / \mathrm{mL}$. The value ranged from $20.14-43.0 \mu \mathrm{g} / \mathrm{mL}$. The Mean \pm SE value of renal clearance of moxifloxacin was found to be $0.476 \pm 0.04$ $\mathrm{mL} / \mathrm{min} / \mathrm{kg}$. Its value ranged from $0.27-0.609 \mathrm{~mL} / \mathrm{min} / \mathrm{kg}$. The Mean \pm S.E value of ratio was $0.203 \pm 0.045$ range $(0.092-0.503)$.

Table 1: Average data of renal clearance of endogenous creatinine and moxifloxacin in 8 healthy male volunteers after oral administration of moxifloxacin $400 \mathrm{mg}$

\begin{tabular}{|c|c|c|c|c|c|c|c|c|c|c|c|}
\hline \multirow{2}{*}{$\begin{array}{l}\text { Sr. } \\
\text { No }\end{array}$} & \multirow{2}{*}{$\begin{array}{c}\text { Body } \\
\text { Wt } \\
\text { Kg }\end{array}$} & \multirow{2}{*}{$\begin{array}{l}\text { Diuresis } \\
\mathrm{ml} / \mathrm{min} \\
/ \mathrm{kg}\end{array}$} & \multicolumn{2}{|c|}{ pH } & \multicolumn{2}{|c|}{$\begin{array}{c}\text { Creat. Conc } \\
\mu \mathrm{g} / \mathrm{ml}\end{array}$} & \multirow{2}{*}{$\begin{array}{c}\text { Creat } \\
\mathrm{Cl} \\
\mathrm{ml} / \\
\mathrm{min} / \mathrm{kg}\end{array}$} & \multicolumn{2}{|c|}{$\begin{array}{c}\text { Drug Conc } \\
\mu \mathrm{g} / \mathrm{ml}\end{array}$} & \multirow{2}{*}{$\begin{array}{c}\text { Renal } \\
\text { Clearance of } \\
\text { drug } \mu \mathrm{g} / \mathrm{ml}\end{array}$} & \multirow{2}{*}{$\begin{array}{l}\text { Cl Ratio Cl } \\
\text { drug/ Cl cr }\end{array}$} \\
\hline & & & Blood & Urine & Plasma & Urine & & Plasma & Urine & & \\
\hline 1 & 68 & 0.048 & 7.46 & 6.13 & 17.2 & 777.3 & 1.17 & 1.89 & 43.0 & 0.591 & 0.503 \\
\hline 2 & 70 & 0.05 & 7.49 & 7.0 & 12.95 & 1637 & 2.953 & 1.74 & 20.14 & 0.270 & 0.092 \\
\hline 3 & 73 & 0.045 & 7.44 & 6.05 & 13.63 & 1187 & 3.18 & 1.59 & 23.56 & 0.540 & 0.170 \\
\hline 4 & 71 & 0.043 & 7.45 & 6.78 & 10.05 & 997.2 & 3.073 & 1.55 & 29.42 & 0.588 & 0.191 \\
\hline 5 & 69 & 0.046 & 7.47 & 6.68 & 11.23 & 1019 & 2.671 & 1.80 & 24.66 & 0.403 & 0.151 \\
\hline 6 & 72 & 0.045 & 7.44 & 5.90 & 10.2 & 889.3 & 2.361 & 1.64 & 24.1 & 0.398 & 0.169 \\
\hline 7 & 74 & 0.047 & 7.50 & 5.58 & 14.18 & 1212. & 2.837 & 1.46 & 26.80 & 0.609 & 0.215 \\
\hline 8 & 70 & 0.045 & 7.46 & 6.10 & 11.45 & 1325 & 3.163 & 1.71 & 25.73 & 0.411 & 0.130 \\
\hline $\begin{array}{l}\text { Mean } \pm \\
\text { SE }\end{array}$ & $\begin{array}{c}70.9 \\
\pm 0.72\end{array}$ & $\begin{array}{c}0.046 \\
\pm 0.0015\end{array}$ & $\begin{array}{c}7.46 \\
\pm 0.007\end{array}$ & $\begin{array}{r}6.28 \\
\pm 0.17\end{array}$ & $\begin{array}{l}12.61 \\
\pm 0.85\end{array}$ & $\begin{array}{l}1130.7 \\
\pm 96.09\end{array}$ & $\begin{array}{c}2.67 \\
\pm 0.24\end{array}$ & $\begin{array}{c}1.68 \\
\pm 0.05\end{array}$ & $27.18 \pm 2.45$ & $0.476 \pm 0.04$ & $\begin{array}{c}0.203 \\
\pm 0.045\end{array}$ \\
\hline
\end{tabular}

\subsection{Correlation between Diuresis, $\mathrm{pH}$ of Urine VS Clearance Ratio}

There is significant $(<0.05)$ positive correlation $(r=0.1356)$ between rate of urine flow and moxifloxacin renal clearance as shown in Figure 1. There is a non-significant and positive correlation $(\mathrm{r}=0.2830)$ between $\mathrm{pH}$ of urine and moxifloxacin clearance as shown in Figure 2.

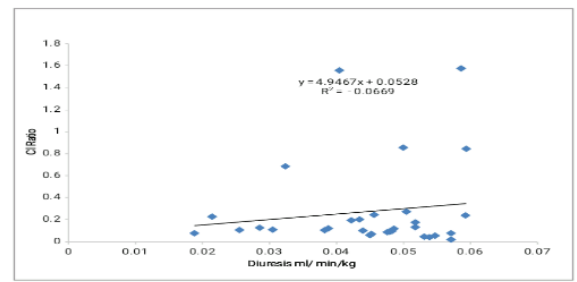

Figure 1: Relationship between $\mathrm{pH}$ of urine and renal clearance of moxifloxacin

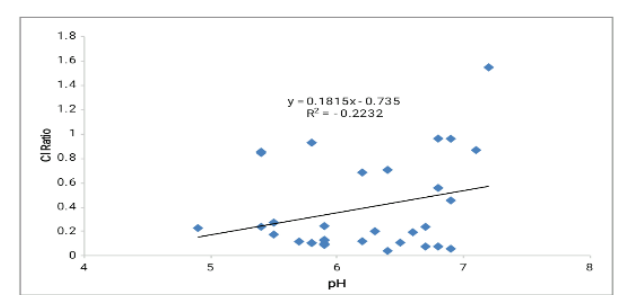

Figure 2: Relationship between diuresis and Renal clearance of moxifloxacin 


\subsection{Urinary Concentration}

The results of urinary excretion of moxifloxacin are expressed in terms of amount excreted in mg and cumulative percentage dose excreted. Dose (mg) of moxifloxacin excreted in urine has been graphically presented in Figure 3. The mean \pm SE value for $\mathrm{mg}$ of dose excreted in urine at $1 \mathrm{hr}$ was $4.28 \pm 0.77 \mathrm{mg}$. At $2 \mathrm{hr}$ mean $\pm \mathrm{SE}$ value was $3.58 \pm 0.64 \mathrm{mg}$. Mean $\pm \mathrm{SE}$ values at 3 and $4 \mathrm{hr}$ were $7.33 \pm 0.55$ and $5.56 \pm 0.81 \mathrm{mg}$ respectively. At 6 and $8 \mathrm{hr}$ the value of mean $\pm \mathrm{SE}$ for dose excreted in mg were7.50 \pm 0.76 and $2.23 \pm 0.47$. Mean \pm SE values were $8.96 \pm 0.29 \mathrm{mg}$ (range $7.36-10.14$ $\mathrm{mg}$ ) at $10 \mathrm{hr}, 20.69 \pm 1.85$ at $12 \mathrm{hr}$, and $9.68 \pm 1.44$ at $24 \mathrm{hr}$. At $36 \mathrm{hr}$ and $48 \mathrm{hr}$ the value of mean \pm SE were $4.16 \pm 0.29 \mathrm{mg}$ and $6.304 \pm 0.65 \mathrm{mg}$ (2.55 - 8.47) respectively. The cumulative percent does of moxifloxacin excreted at 12, 24, 36 and $48 \mathrm{hr}$ post medication of moxifloxacin $400 \mathrm{mg}$ oral administration in urine male volunteers is presented in Table 2. Mean $\pm \mathrm{SE}$ values was $15.4 \pm 0.61$ (range $13.64-18.22$ ) at $12 \mathrm{hr}, 17.86 \pm 0.70$ (range $16.05-21.10$ ) at $24 \mathrm{hr}, 18.90 \pm 0.76$ (range $0.26-3.10$ ) at $36 \mathrm{hr}$. At $48 \mathrm{hr}$ the value of mean $\pm \mathrm{SE}$ was $20.48 \pm 0.88 \%$ (ranged from 17.61 24.71) respectively.

Table 2: Cumulative percent dose excreted in urine after oral administration of moxifloxacin 400 mg in eight volunteers

\begin{tabular}{|c|c|c|c|c|}
\hline \multirow{2}{*}{$\begin{array}{l}\text { Sr. } \\
\text { No }\end{array}$} & \multicolumn{4}{|c|}{ Time hr } \\
\hline & 12 & 24 & 36 & 48 \\
\hline 1 & 18.22 & 21.10 & 22.59 & 24.71 \\
\hline 2 & 16.18 & 16.43 & 17.44 & 19.16 \\
\hline 3 & 13.64 & 16.49 & 17.32 & 19.05 \\
\hline 4 & 17.63 & 20.74 & 21.89 & 23.84 \\
\hline 5 & 15.1 & 18.1 & 19.08 & 20.32 \\
\hline 6 & 14.16 & 17.08 & 18.05 & 19.57 \\
\hline 7 & 14.6 & 16.05 & 16.97 & 17.61 \\
\hline 8 & 14.01 & 16.91 & 17.88 & 19.55 \\
\hline $\begin{array}{c}\text { Mean } \\
\pm S E\end{array}$ & $\begin{array}{c}15.4 \\
\pm 0.61\end{array}$ & $\begin{array}{l}17.86 \\
\pm 0.70\end{array}$ & $\begin{array}{r}18.90 \\
\pm 0.76\end{array}$ & $\begin{array}{r}20.48 \\
\pm 0.88\end{array}$ \\
\hline
\end{tabular}

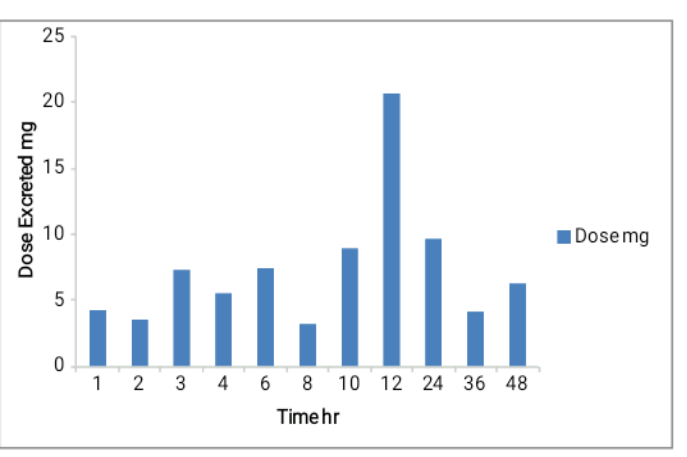

Figure 3: Mean dose (mg) of moxifloxacin excreted urine after oral administration of moxifloxacin $400 \mathrm{mg}$ in male volunteers

\section{DISCUSSION}

There is no single mechanism to describe renal handling of endogenous and exogenous substances. The multiple mechanisms of glomerular filtration, active or passive back diffusion and active secretion, alone or in combination, are involved in the renal handling of these substances. It was studied that fluoroquinolones (FQs) exist as charged molecules in blood and urine making their absorption, distribution, and elimination likely to be affected by active transport mechanisms. Due to their zwitter ionic nature, fluoroquinolones are likely to interfere with cation transporters and organic anion within the solute carrier (SLC) superfamily. The ATP binding cassette $(\mathrm{ABC})$ transporters also may interact with them [7]. The main functions of kidney are urine formation and water conservation, and this is the major channel of water excretion as compared to intestine, skin and lungs. As the glomerular filtrate flow through the tubules, over $99 \%$ of its water and varying amount of its solute are normally are absorbed into the vascular system and small amounts of some substances are secreted into the tubules. The remaining tubular water and dissolved substances become urine [8]. The average \pm SD for rate urine flow in this study is $0.046 \pm 0.0007 \mathrm{ml} / \mathrm{min} / \mathrm{Kg}$. This value is comparable to mean $\pm \mathrm{SE}$ value for diuresis $0.018 \pm 0.0056 \mathrm{ml} / \mathrm{min} / \mathrm{Kg}$, ranged from 0.011 to 0.05 $\mathrm{ml} / \mathrm{min} / \mathrm{Kg}$ [9]. The volume and composition of body fluid is mainly regulated kidneys through an adjustment in composition and volume of urine voided which profoundly influenced by environmental temperature. As in summer evaporation via sweating causes reduced urine flow during summer, while lower temperature of winter increases the urine flow in winter. It has been observed in mammal including humans propose that variation in serum creatinine (SC) and estimated glomerular filtration rate (eGFR) may take place during summer [10].

Renal clearance of endogenous creatinine is used as an index of glomerular filtration rate (GFR). In present study renal clearance of endogenous creatinine ranges from 1.17 to $3.18 \mathrm{ml} / \mathrm{min} / \mathrm{Kg}$ with an average $\pm \mathrm{SE}$ value of $2.67 \pm 0.24 \mathrm{ml} / \mathrm{min} / \mathrm{Kg}$ which are comparable to mean $\pm \mathrm{SE}$ value 0.519 \pm 0.068 ranged from 0.379 to $0.911 \mathrm{ml} / \mathrm{min} / \mathrm{Kg}$ reported in an earlier study
[9]. Such differences have already been found not only in human being but also in other species under indigenous showing GFR (creatinine clearance) values that are higher than the values given in literature. The reason might be environmental influences on genetics [11]. The mean $\pm \mathrm{SE}$ value of renal clearance of moxifloxacin in present study was $0.476 \pm 0.043 \mathrm{ml} / \mathrm{min} \mathrm{Kg}$, ranged between $0.27-0.609 \mathrm{ml} / \mathrm{min} / \mathrm{Kg}(26.37 \mathrm{ml} / \mathrm{min})$. It was comparable to the mean value of renal clearance of moxifloxacin that was $1.3-3 \mathrm{~L} / \mathrm{hr}(35.83 \mathrm{ml} / \mathrm{min})$ reported in an earlier study [12]. The clearance equals the GFR if there is no net tubular secretion or reabsorption. The clearance of substance exceeds the GFR if there is net tubular secretion and is less than the GFR if there is net tubular reabsorption [13]. The mean \pm SE value for clearance ratio between clearance of drug and creatinine clearance was $0.2025 \pm 0.045$. This value indicates reabsorption (back diffusion) of moxifloxacin. Renal clearance of moxifloxacin 40-51 $\mathrm{ml} / \mathrm{min} / 1.73 \mathrm{~m}^{2}(2.4$ to $3.0 \mathrm{~L} / \mathrm{hr}$ ) has shown approximately $52 \%$ partial tubular reabsorption of the drug [14]. The results of dieresis in relation to clearance were plotted in Figure 1 . There is a significant positive correlation between the two parameters. The positive correlation between diuresis and clearance indicated that besides glomerular filtration, passive diffusion of drug is at kidney tubular level. Drugs bound to serum proteins remain in the circulation; only unbound drug is contained in the glomerular filtrate. Un-ionized forms of drugs and their metabolites tend to be reabsorbed readily from tubular fluids $[3,8]$. The urine $\mathrm{pH}$ and the clearance ratio have been plotted in Figure 2. From the figure it is seen that there is trend of positive correlation although the correlation is non-significant. Renal excretion accounts for most drug elimination that are predominately ionized at physiological $\mathrm{pH}$ and for polar drugs, drug metabolites with low lipid solubility [8].

The cumulative percentage of moxifloxacin excreted in urine male volunteers is presented in Table 2 . After $48 \mathrm{hr}$ of oral administration of moxifloxacin, mean \pm SE values $20.48 \pm 0.88$ percent of total dose was excreted in urine. The urinary excretion of the unchanged moxifloxacin accounts for only $19-22 \%$ of the given dose after $48 \mathrm{hr}$ of oral administration [15]. 20\% of administered dose is excreted in urine [16]. In $48 \mathrm{hr}$ the mean urinary excretion of the drug was $15.1 \%$ [17]. Over 24 $\mathrm{hr}, 15 \%$ of drug was recovered in urine when administer by either route [18]. Only $20 \%$ of administered the drug was excreted by the kidney as unchanged parent drug [19]. The difference in the urinary excretion under local condition is due to environment and genetics [20].

\section{CONCLUSION}

The present study demonstrated considerable variation in the renal clearance of moxifloxacin in healthy male volunteers with similar studies conducted under different environmental conditions. This study indicates that renal clearance of moxifloxacin is affected by genome, temperature, life style and environmental conditions in population in local population. The results of urinary excretion of moxifloxacin were almost similar as indicated in literature, so this data shows that urinary excretion of moxifloxacin is not affected by genome temperature life style and environmental conditions in population in local population. 


\section{REFERENCES}

[1] Yildiz, F., Kurtaran, B., Çayli, M., Candevir, A., Sumbul, Z. 2008. A significant interaction between moxifloxacin and warfarin in a patient with a mitral bio prosthetic valve. Heart and vessels, 23, 286-288.

[2] Culley, C.M., Lacy, M.K., Klutman, N., Edwards, B. 2001. Moxifloxacin: clinical efficacy and safety. American journal of health-system pharmacy, $58,379-388$.

[3] Iqbal, Z., Javed, I., Aslam, B., Muhammad F., Jan, I.U. 2007. Renal clearance and urinary excretion of ciprofloxacin in goats. Pakistan veterinary journal, $27,179-183$.

[4] Javed, I., Iqbal, Z., Rehman, Z.U., Muhammad, F., Aslam B., Sandhu M.A., Sultan, J.J. 2009. Disposition kinetics and optimal dosage of ciprofloxacin in healthy domestic ruminant species. Acta Veterinary bron, 78, 155-162.

[5] Levey, A.S., Stevens, L.A., Schmid, C.H., Zhang, Y., Castro, A.F., Feldman H.I., Kusek, J. W., Eggers, P., Lente, F.V., Greene, T., Coresh, J. 2009. A new equation to estimate glomerular filtration rate. Annals of internal medicine, 150, 604-612.

[6] Ballesteros, O., Toro, I., Sanz-Nebot, V., Navalon, A., Vllchez, J., Barbosa, J. 2003. Determination of fluoroquinolones in human urine by liquid chromatography coupled to pneumatically assisted electrospray ionization mass spectrometry. Journal of chromatography B: biomedical sciences and applications, 798,137-144.

[7] Mulgaonkar, A., Venitz, J., Sweet, D.H. 2012. Fluoroquinolone disposition: identification of the contribution of renal secretory and resorptive drug transporters. Expert opinion on drug metabolism and toxicology, 8, 553-569.

[8] Bilal, A., Sohail, I., Iqbal, T., Ghaffar, A., Munir, B. 2015. Urinary excretion and renal clearance of allopurinol in female goat patients. J Anal Bio anal tech, 6-3.

[9] Waheed, N., Iqbal, T., Sheikh, M.A., Khan, F.H. 2002. Renal clearance of endogenous creatinine and levofloxacin in male volunteers. Journal of medical sciences, 2, 145-148.

[10] Ranucci, M., Castelvecchio, S., La Rovere, M.T. 2014. Renal function changes and seasonal temperature in patients undergoing cardiac surgery. Chronobiology international, 31, 175-181.
[11] Muhammad, F. 1997. Disposition kinetics, renal clearance and urinary excretion of kanamycinin mules. M. Sc. Thesis. Department of physiology and pharmacology, university of agriculture, Faisalabad.

[12] Balfour, J. A. B., Lamb, H. M. 2000. Moxifloxacin. Drugs, 59, 115-139.

[13] Buxton, I.L.O. 2006. Pharmacokinetics and pharmacodynamics: the dynamics of drug absorption, action, and elimination. In: Goodman and Gillman's the pharmacological basis of therapeutics. $11^{\text {th }}$ Ed. Mc Graw Hill, New York.

[14] Stass, H., Dalhoff, A., Kubitza, D., Schuhly, U. 1998. Pharmacokinetics, safety, and tolerability of ascending single doses of moxifloxacin, a new 8methoxy quinolone, administered to healthy subjects. Antimicrobial agents chemotherapy, 42, 2060-2067.

[15] Moise, P., Birmingham, Schentag, J. 2000. Pharmacokinetics and metabolism of moxifloxacin. Drugs today (Barcelona), 36, 229-244.

[16] Gonzalez, I., Lobera, T., Blasco A., del Pozo, M.D. 2005. Immediate hypersensitivity to quinolones: moxifloxacin cross reactivity. Journal investigational allergology clinical immunology, 15, 146-149.

[17] Wagenlehner, F.M., Kinzig-Schippers, M., Sörgel, F., Weidner, W., Naber. 2006. Concentrations in plasma, urinary excretion and bactericidal activity of levofloxacin $(500 \mathrm{mg})$ versus ciprofloxacin $(500 \mathrm{mg})$ in healthy volunteers receiving a single oral dose. International journal of antimicrobial agents, 28, 551-559.

[18] Wise, R., Andrews, J.M., Marshall, G., Hartman, G. 1999. Pharmacokinetics and inflammatory-fluid penetration of moxifloxacin following oral or intravenous administration. Antimicrobial agents and chemotherapy, 43, 1508-1510.

[19] Czock, D., Husig-Linde, C., Langhoff, A., Schopke, T., Hafer, C., de Groot, K., Swoboda, S., Kuse, E., Haller, H., Fliser, D., Keller, F., Kielstein, J.T. 2006. Pharmacokinetics of moxifloxacin and levofloxacin in intensive care unit patients who have acute renal failure and undergo extended daily dialysis. Clinical journal of the American society of nephrology, 1, 12631268.

[20] Ballow, C., Lettieri, J., Agarwal, V., Liu, P., Stass H., Sullivan, J.T. 1999. Absolute bioavailability of Moxifloxacin. Clinical Therapeutics, 21, 513522. 